\title{
ANALYSIS OF THE EFFECT OF RETURN ON ASSETS, EARNINGS PER SHARE, INFLATION RATE, AND INTEREST RATE ON STOCK RETURN: A CASE STUDY OF SOE BANKING COMPANIES LISTED IN INDONESIA STOCK EXCHANGE
}

\author{
Saputra Imanuel Sebrian Dwi ${ }^{\star}$ \\ Graduate Program, University of Gunadarma, Jakarta, Indonesia \\ Wardoyo, Lecturer \\ University of Gunadarma, Jakarta, Indonesia \\ *E-mail: imanuel.sebrian@gmail.com \\ ORCID: 0000-0003-3820-2268
}

\begin{abstract}
One of the means for medium and long-term investments is the capital market. Capital market is the most effective means for investors to invest in profits. This research aims to analyze the effect of changes in Return on Assets (ROA), Earnings per Share (EPS), Inflation Rate, and Interest Rate on stock return in SOE banks listed on the Indonesia Stock Exchange within the research period of 2012-2016. This research uses secondary data. The research population is the financial statements of 4 Persero Banks including PT Bank Negara Indonesia Tbk, PT Bank Rakyat Indonesia Tbk, PT Bank Mandiri Tbk, and PT Bank Tabungan Negara Tbk within the research period of 5 years from 2012 to 2016 . Research sampling was conducted using the purposive sampling method. The data analysis was carried out using classical assumption test, multiple linear regression analysis, t-test, and Ftest with the help of SPSS 19. The research findings showed that the Interest Rate partially has a significant effect on Stock Return. Meanwhile, ROA, EPS, and Inflation Rate partially do not have a significant effect on Stock Return. Moreover, simultaneously ROA, EPS, Inflation Rate and Interest Rate have a significant effect on Stock Return.
\end{abstract}

\section{KEY WORDS}

Return on assets, earnings per share, inflation rate, interest rate, stock return.

Investment is a commitment to a number of funds or other resources which currently aims to obtain a number of benefits in the future (Tandelilin, 2001). One of the means for medium and long-term investments is the capital market. Capital market is the most effective means for investors to invest in profits. Capital market is a solution between capital owners in this case referred to the investors - who have more funds and borrowers of funds - in this case referred to the issuers (go-public companies) - which requires capital to run its business. Investors request capital market instruments for portfolio investment purposes. Thus, in the end it can maximize the income.

Capital market instruments are divided into two major groups consisting of owner instruments (equity) such as stocks and debt instruments (bonds) such as corporate bonds, subscription bonds, bonds that can be converted into shares, and so forth. Stocks become one of the alternative investments in the capital market that are most widely used by investors because it has the potential to obtain greater profits, in which the funds needed by investors to make investments are not so large compared to bonds.

According to Tandelilin (2001), the main reason an investor invests or purchases shares is to get a profit or return. Return is divided into 2 types, namely capital gains and dividends. Capital gain is the positive difference between the selling price and the purchase price of the stock while dividends are profits received from the issuer because the company gains profit (lannotta, 2014).

Based on fundamental analysis, there are several financial ratios that can reflect the financial condition and performance of a company. Ang et al., (2000) classified financial 
ratios into five which include liquidity, solvability, profitability, activity and market ratios. These financial ratios are used to explain the strengths and weaknesses of the financial condition of a company and to predict stock return in the capital market. The ratios used in this research include the profitability, solvency and market ratios. The profitability ratio that functions and which is often used to predict stock price or stock return is Return on Assets (ROA) and Earnings oer Share (EPS). Return on Assets (ROA) is used to measure the effectiveness of a company in generating profits by utilizing assets owned. If Return on Assets (ROA) increases, then the company's performance will also increase, because the rate of return is increasing (Hardiningsih et.al., 2002). In fact, Ang et al., (2000) mentioned that Return on Assets (ROA) is the most important ratio compared to profitability ratio in predicting stock return. In addition, Earnings per Share (EPS) is a comparison between earnings (in this case after-tax net income) and the number of shares of the company. For investors, EPS is information that is considered the most basic and useful, because it can describe the company's earnings prospects in the future (Tandelin, 2001). EPS shows the level of profit for each share. Large EPS generates large profits that shareholders will receive. In other words, this shows that the operational conditions of the company are getting better (Darmadji \& Fakhruddin, 2001).

In addition, in the external factors, there are also factors that affect stock return in the capital market. The factor that appears to be very influential on the level of stock return is the inflation rate. High inflation rates indicate that the investment risk is quite high because it will reduce the rate of return from investors. In high inflation condition, the price of goods or raw materials has a tendency to increase. The increase in prices of goods and raw materials will increase production costs so that it will affect the decrease in the number of requests and sales which then reduce the company's revenue. Furthermore, it will have a negative impact on company performance which is also reflected by the decline in stock return (Prihantini, 2009). Similar case happens at interest rates. Changes in interest rates will affect stock prices in reverse (ceteris paribus). In other words, if the interest rate increases, then the stock price will decrease and vice versa. It will affect stock return (Tandelilin, 2001).

In predicting stock prices, there is a basic approach consisting of fundamental and technical analyses. Those analyses are used to determine the company's financial performance using ratios. Commonly, measuring the performance of a company uses financial ratio analysis consisting of liquidity, leverage and profitability ratios. By knowing how to analyze financial ratios and their effect on the company's stock price, it can help companies determine how to meet their needs should be carried out so that the company's goal in maximizing the prosperity of shareholders can be achieved through increasing stock prices.

\section{METHODS OF RESEARCH}

The research applied quantitative method using a combination of cross section and time series data. The data were obtained from Bank Indonesia and other sources that support the fulfillment of data. The method of data processing includes hypothesis testing, multiple regression coefficient analysis simultaneously ( $F$ test) and partially (t-test), and the overall and partial results of multiple regression. To support these findings, the descriptive analysis test was conducted with the aim to summarize the data and display the in the table in the form of Minimum, Maximum, Mean and Deviation Standard along with the classical assumption test which aims to see whether or not the independent variables meet the requirements. Thus, so that the results of the hypothesis testing are not bias.

The research population is the annual financial statements of 4 SOE banks consisting of PT Bank Negara Indonesia Tbk, PT Bank Rakyat Indonesia Tbk, PT Bank Mandiri Tbk, and PT Bank Tabungan Negara Tbk within the research period of 5 years from 2012 to 2016. Research sampling was conducted by using a purposive sampling method because the sample has criteria including: go-public SOE Banks listed on the Indonesia Stock Exchange and has complete financial statements during the period of 2012-2016. Thus, the number of 
observations was 20 times obtained from $4 \times 5$ (multiplication between the number of banks and the year of observation period).

To determine the effect of Return on Assets (ROA), Earnings per Share (EPS), Inflation Rate, and Interest Rate on Stock Return, multiple regression analysis is used. The use of multiple regression analysis aims to create a mathematical model of the effect of Return on Assets (ROA), Earnings per Share (EPS), Inflation Rate and Interest Rate on Stock Return. From this model, we can determine the effect of Return on Assets (ROA), Earnings per Share (EPS), Inflation Rate and Interest Rate on Stock Return. The general form of the regression equation is multiple linear regression as follows:

$$
R S=a+b_{1} R O A+b_{2} E P S+b_{3} T I+b_{4} T S B+\varepsilon
$$

Where: $\alpha=$ Constant of Regression Equations; ROA = Return on Assets; EPS = Earnings per Share; $\mathrm{TI}=$ Inflation Rate; TSB = Interest Rate; RS = Stock Return; $b_{1}-b_{3}=$ Regression Coefficient; $\varepsilon=$ Random Error.

The F-test is carried out to find out whether or not in the regression model the independent variables $\left(X_{1}, X_{2}, \ldots, X_{n}\right)$ simultaneously have significant effect on the dependent variable $(Y)$. The significance of the ANOVA table shows the magnitude of the probability or significance value in the ANOVA calculation. The listed values are used for feasibility analysis model in which a number of variables $X$ affects $Y$ variable with the provision that a good probability number to be used as a regression model must be $<0.05$. This value can be seen in the Sig. column. If Sig. value $<0.05$, the analysis model is considered feasible. If Sig. $>0.05$, then the analysis model is considered not feasible.

The hypothesis for this ANOVA test is:

- If Sig. value $<0.05 \mathrm{H}_{0}$ is rejected;

- If Sig. value $>0.05 \mathrm{H}_{\mathrm{a}}$ is accepted.

The t-test is carried out to find out whether or not in the regression model the independent variables $\left(X_{1}, X_{2}, \ldots ., X_{n}\right)$ partially have significant effect on the dependent variable $(Y)$. The independent variables can explain the dependent variable which can be seen from each of the independent variables. If the significance value is 0.000 , it is considered to be very significant. The testing in SPSS uses the following criteria:

- If the significant value of the research results is $<0.05$, then the correlation between variables is significant;

- If the significant value of the research results is $>0.05$, then the correlation between variables is not significant.

\section{RESULTS AND DISCUSSION}

Dynamics Chart of All Research Variables:

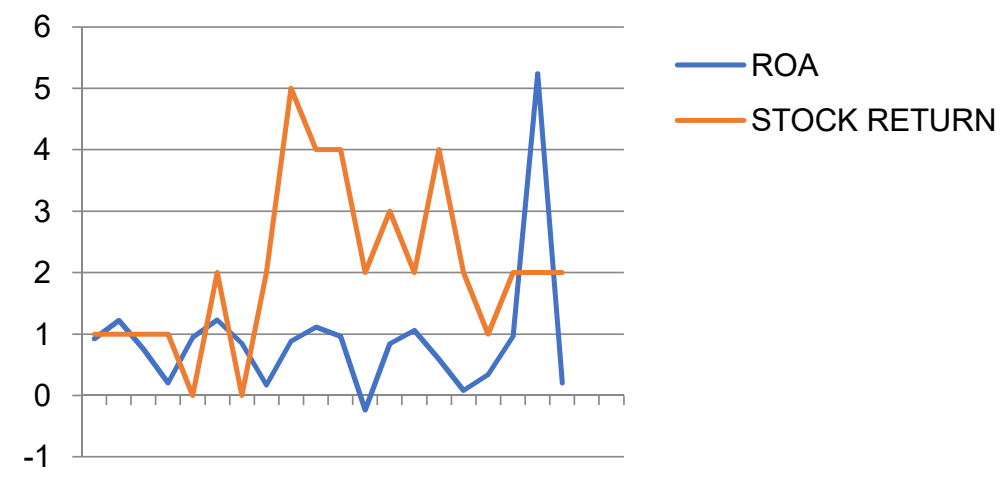

Figure 1 - Chart of Return on Assets (ROA) and Stock Return. Independent Variable (ROA) on Dependent Variable (Stock Return) in SOE Banks Listed on the Indonesia Stock Exchange in the Period of 2012-2016 (Source: www.idx.co.id \& https://finance.yahoo.com) 
Figure 1 above shows that the pattern of ROA is not the same as Stock Return. The increase or decrease is not in line with Stock Return. If a company's ROA increases, Stock Return will not necessarily increase. Conversely, if the ROA decreases, Stock Return does not necessarily decrease. However, based on the chart of the two variables, the results do not reflect the previous theories and research which states that if ROA increases then the Stock Return will increase.

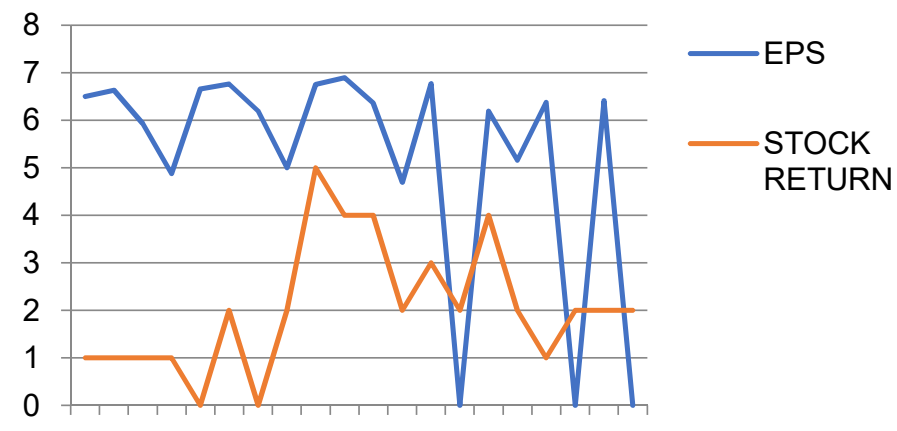

Figure 2 - Chart of Earning per Share (EPS) and Stock Return. Independent Variable (EPS) on Dependent Variable (Stock Return) in SOE Banks Listed on the Indonesia Stock Exchange in the Period of 2012-2016 (Source: www.idx.co.id \& https://finance.yahoo.com)

Figure 2 above shows that the pattern of EPS is not the same as Stock Return. The increase or decrease is not in line with Stock Return. If a company's EPS increases, Stock Return will not necessarily increase. Conversely, if the ROA decreases, Stock Return does not necessarily decrease. However, based on the chart of the two variables, the results do not reflect the previous theories and research which states that if EPS increases then the Stock Return will increase.

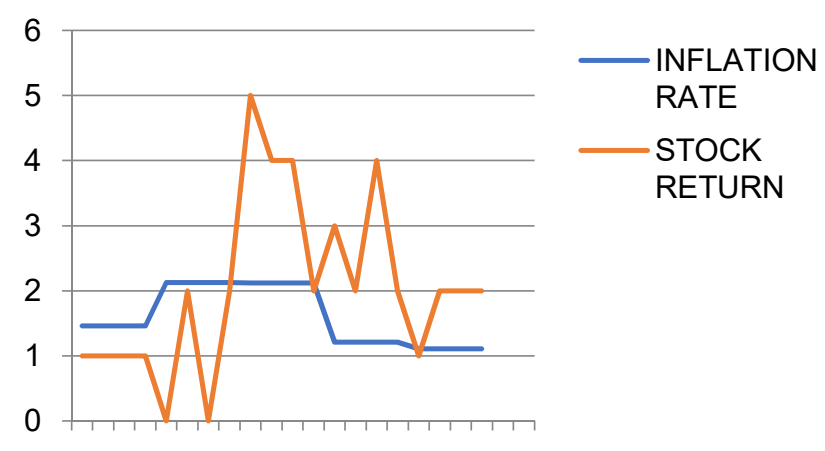

Figure 3 - Chart of Inflation Rate and Stock Return. Independent Variable (Inflation Rate) on Dependent Variable (Stock Return) in SOE Banks Listed on the Indonesia Stock Exchange in the Period of 2012-2016 (Source: www.idx.co.id \& https://finance.yahoo.com)

Figure 3 above shows that the inflation rate pattern is not the same as stock return. The increase or decrease in inflation is not inversely proportional to stock return. If inflation in a country increases, stock return may not inversely decrease. Conversely, if inflation decreases, Stock Return is not necessarily inversely experiencing an increase. However, based on the graph of the two variables, the results do not reflect the previous theories and research which states that if the Inflation Rate increases then the Stock Return will decrease.

Figure 3 above shows that the interest rate pattern is not the same as stock return. The increase or decrease in interest rate is not inversely proportional to stock return. If the interest rate in a country increases, stock return may not inversely decrease. Conversely, if the interest rate decreases, Stock Return is not necessarily inversely experiencing an increase. However, based on the graph of the two variables, the results do not reflect the 
previous theories and research which states that if the Interest Rate increases then the Stock Return will decrease.

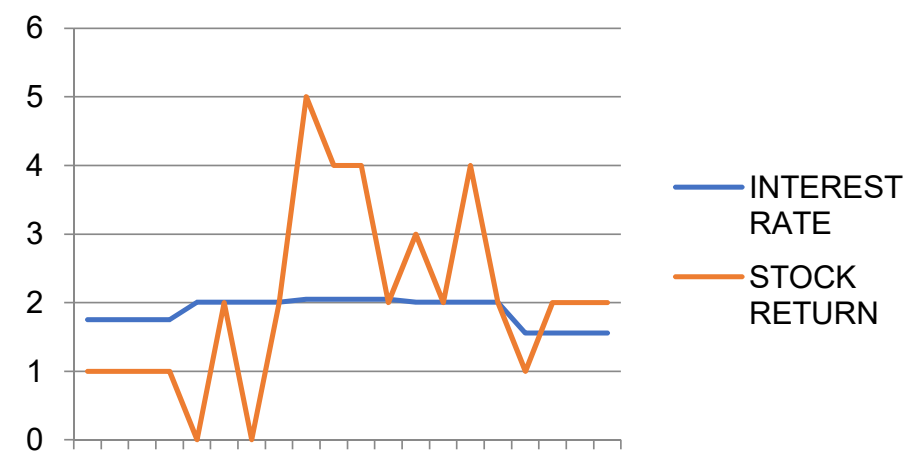

Figure 4 - Chart of Interest Rate and Stock Return. Independent Variable (Inflation Rate) on Dependent Variable (Stock Return) in SOE Banks Listed on the Indonesia Stock Exchange in the Period of 2012-2016 (Source: www.idx.co.id \& https://finance.yahoo.com)

Multiple Linear Regression Analysis. Regression analysis is used to analyze the effect of independent variables on the dependent variable. In this research, multiple regression analysis was used to analyze the effect of Return on Assets (ROA), Earnings per Share (EPS), Inflation Rate and Interest Rate on Stock Return. The coefficient of the independent variables in the multiple regression equation will be interpreted using Standardized Beta Coefficients. The statistical calculation in the multiple linear regression analysis in this study was carried out with the help of the SPSS computer program for Windows version 19. The results of processing are explained in Table 1 below.

Table 1 - Results of Linear Regression Test

Coefficients $^{\mathrm{a}}$

\begin{tabular}{|c|c|c|c|}
\hline & \multirow{2}{*}{ Model } & \multicolumn{2}{|c|}{ Unstandardized Coefficients } \\
\hline & & B & Std. Error \\
\hline \multirow{5}{*}{1} & (Constant) & -4.234 & 1.330 \\
\hline & Ln_ROA & -.013 & .244 \\
\hline & Ln_EPS & .175 & .084 \\
\hline & Ln_IFR & .025 & .303 \\
\hline & Ln_ITR & 2.021 & .677 \\
\hline
\end{tabular}

Source: Processing Results from SPSS 19 Program.

Based on the table, the regression equation is as follow:

$$
S R=-4.234-0.013 R O A+0.175 E P S+0.025 I F R+2.021 I T R
$$

Where: $\mathrm{SR}=$ Stock Return; ROA = Return on Assets; $\mathrm{EPS}=$ Earnings per Share; IFR = Inflation Rate; ITR = Interest Rate.

The results of the analysis are interpreted as follows:

- The constant of -4.234 shows that if Return on Assets (ROA), Earnings per Share (EPS), Inflation Rate and Interest Rate are zero, the Stock Return is equal to -4.234;

- Return on Assets (ROA) (X1) value of -0.013 shows that if the ROA variable increases by one unit, the Stock Return variable will decrease by -0.013 assuming that the other independent variables of the regression model are fixed;

- Earnings per Share (EPS) (X2) value of 0.175 shows that if the EPS variable increases by one unit, the Stock Return variable will increase by 0.175 assuming that the other independent variables of the regression model are fixed; 
- Inflation Rate (X3) value of 0.025 indicates that if the inflation variable increases by one unit then the Stock Return variable will increase by 0.025 assuming that the other independent variables of the regression model are fixed;

- Interest Rate (X4) value of 2.021 shows that if the Interest Rate variable increases by one unit, the Stock Return variable will increase by 2.021 assuming that the other independent variables of the regression model are fixed.

Determination Coefficient Analysis $\left(R^{2}\right)$. The determination coefficient is used to find out the correlation of several variables in a clearer sense. The determination coefficient will explain how much change or variation a variable can be explained by changes or variations on other variables. This coefficient value is between 0 and 1 . If the results are closer to the number 0 , the ability of the independent variables to explain variable variations is very limited. On the other hand, if the results close to 1 , it means that the independent variables provide almost all the information needed to predict variations in the dependent variable.

Table 2 - Results of Determination Coefficient Test $\left(R^{2}\right)$

Model Summary

\begin{tabular}{|c|c|c|c|c|c|}
\hline Model & $\mathrm{R}$ & $\mathrm{R}$ Square & Adjusted R Square & Std. Error of the Estimate & Durbin-Watson \\
\hline 1 & $.733^{\mathrm{a}}$ & .537 & .395 & .41530 & 1.290 \\
\hline
\end{tabular}

a. Predictors: (Constant), Ln_ROA, Ln_EPS, Ln_IFR, Ln_ITR

b. Dependent Variable: Ln_SR

Source: Processing Results from SPSS 19 Program

Based on Table 2, the Adjusted R Square value is 0.395 . Adjusted R Square is also called the determination coefficient so that in this case the percentage of the effect of the independent variables (Return on Assets (ROA), Earnings Per Share (EPS), Inflation Rate and Interest Rate) on the dependent variable (Stock Return) is $39.5 \%$. While the remaining $60.5 \%$ is affected or explained by other variables not included in this research. The Standard Error of the Estimate is a measure of the number of errors in the regression model in predicting the $Y$ value. The regression results get a value of 0.41530 which means that the stock return prediction error is 0.41530 units.

\section{RESULTS OF STUDY}

According to Sugiyono (2006), the F Test is a test tool that aims to determine whether there is a significant effect simultaneously between the independent variables consisting of Return on Assets (ROA) (X1), Earnings per Share (EPS) (X2), Inflation Rate (X3) and Interest Rate (X4) and the dependent variable is Stock Return (Y). In addition, this model aims to determine whether the independent variables $(\mathrm{X} 1, \mathrm{X} 2 \ldots \mathrm{Xn})$ simultaneously have a significant effect on the dependent variable $(Y)$. The basis of the decision-making criteria through significant probability numbers are as follows:

1. If the probability $F$ is $>0.05$, then $H_{0}$ is accepted and $H_{a}$ is rejected;

2. If the probability $F$ is $<0.05$, then $H_{0}$ is rejected and $H_{a}$ is accepted.

The results of the $\mathrm{F}$ test can be seen in the following table:

Table 3 - F-Test Results

ANOVA $^{\mathrm{D}}$

\begin{tabular}{|c|c|c|c|c|c|}
\hline Model & Sum of Squares & Df & Mean Square & $\mathrm{F}$ & Sig. \\
\hline $\begin{array}{cc} & \text { Regression } \\
1 & \text { Residual } \\
\text { Total }\end{array}$ & $\begin{array}{l}2.605 \\
2.242 \\
4.847 \\
\end{array}$ & $\begin{array}{c}4 \\
13 \\
17\end{array}$ & $\begin{array}{l}.651 \\
.172\end{array}$ & 3.776 & $.030^{a}$ \\
\hline
\end{tabular}

a. Predictors: (Constant, Ln_ROA, Ln_EPS, Ln_IFR, Ln_ITR)

b. Dependent Variable: Ln_SR

Source: Processing Results from SPSS 19 Program 
Based on Table 3 the results of the $F$ test obtained the Sig. 0.03 or $<0.05$, which means that $\mathrm{H}_{0}$ is rejected. Therefore, it is concluded that there is a significant effect between the variables Return on Assets (ROA) (X1), Earnings per Share (EPS) (X2), Inflation Rate (X3) and Interest Rate (X4) simultaneously on Stock Return.

According to Kuncoro (2000), t-test is used to determine whether or not the independent variables of Return on Assets (ROA) (X1), Earnings per Share (EPS) (X2), Inflation Rate (X3) and Interest Rate (X4) are partially significant to the dependent variable of Stock Return with a significant level of 0.05 or $5 \%$. Decision making can be conducted by looking at the probability values. If the probability value is smaller than 0.05 , then $\mathrm{H}_{0}$ is rejected. On the other hand, if the probability is greater than 0.05 then $\mathrm{H}_{0}$ is accepted. Decision making can also be conducted by looking at the t table in the value using a significance value of $5 \%$ or 0.05 for the number of data $n=20$ and the number of research variables $k=5$. Meanwhile, the free degree of testing is $n-k=20-5=15$ then t table value is 2.131 . The results of the t-test are presented in the following table:

Table 4 - t-Test Results

Coefficients $^{a}$

\begin{tabular}{|c|c|c|c|c|c|c|}
\hline & \multirow{2}{*}{ Model } & \multirow{2}{*}{$\frac{\text { Standardized Coefficients }}{\text { Beta }}$} & \multirow{2}{*}{$\mathrm{T}$} & \multirow{2}{*}{ Sig. } & \multicolumn{2}{|c|}{ Collinearity Statistics } \\
\hline & & & & & Tolerance & VIF \\
\hline \multirow{5}{*}{1} & (Constant) & & -3.184 & .007 & & \\
\hline & Ln_ROA & -.011 & -.055 & .957 & .894 & 1.119 \\
\hline & Ln_EPS & .448 & 2.076 & .058 & .764 & 1.309 \\
\hline & Ln_IFR & .021 & .083 & .935 & .576 & 1.737 \\
\hline & Ln_ITR & .767 & 2.985 & .011 & .538 & 1.858 \\
\hline
\end{tabular}

Source: Processing Results from SPSS 19 Program.

Return on Assets (ROA) on Stock Return. Based on the test results in Table 4, the $t$ value for the Return on Assets (ROA) variable is $t=-0.055$ with a significance value of 0.935 $>0.05$. The significance value above 0.05 indicates that Return on Assets (ROA) does not have a significant effect on Stock Return. This is reinforced by the value of $t$ calculate of 0.055 , in which the value of $t$ calculate is between $-2.131<t$ calculate $<+2.131$. It means that hypothesis 1 is rejected.

Earnings per Share (EPS) on Stock Return.Based on the test results in Table 4, the $t$ value for the Earnings per Share (EPS) variable is $t=2.076$ with a significance value of $0.058>0.05$. The significance value above 0.05 indicates that Earnings per Share (EPS) does not have a significant effect on Stock Return. This is reinforced by the value of $t$ calculate of 2.076, in which the value of $t$ calculate is between $-2.131<t$ calculate $<+2.131$. It means that hypothesis 2 is rejected.

Inflation Rate on Stock Return. Based on the test results in Table 4, the t value for the Inflation Rate variable is $t=0.083$ with a significance value of $0.935>0.05$. The significance value above 0.05 indicates that the Inflation Rate does not have a significant effect on Stock Return. This is reinforced by the value of $t$ calculate of 0.083 , in which the value of $t$ calculate is between $-2.131<\mathrm{t}$ calculate $<+2.131$. It means that hypothesis 3 is rejected.

Interest Rate on Stock Return. Based on the test results in Table 4, the t value for the Interest Rate variable is $t=2.985$ with a significance value of $0.011<0.05$. The significance value below 0.05 indicates that the Interest Rate has a significant effect on Stock Return. This is reinforced by the value of $t$ calculate of 2.985 , in which the value of $t$ calculate is above $2.131(2.985>2.131)$. It means that hypothesis 4 is accepted.

\section{DISCUSSION OF RESULTS}

Determining the Effect of Return on Assets (ROA) on Stock Return. The results of partial test (t-test) between the ROA variable and Stock Return variable obtain t calculate value of -0.055 , the regression coefficient of -0.013 , and the probability value of 0.957 which 
is greater than 0.05. It means that ROA does not have significant effect on SOE Banks' Stock Returns. Therefore, the hypothesis stating that the ROA ratio has significant effect on Stock Return is rejected.

The analysis results showed that the ROA ratio does not have significant effect on Stock Return. It is indicated by a probability value of 0.935 which is greater than 0.05 . Therefore, changes in ROA do not cause significant changes in Stock Return obtained by investors. This research findings support Asna and Graha (2006) who found that Return on Assets (ROA) does not have effect on Stock Return but do not support Anisa (2015) who found that Return on Assets (EPS) has effect on Stock Return.

We know that ROA is a ratio used to measure the ability of company assets to generate net income. The high ROA shows the high ability of the company to generate profits from the assets or profitability of the company. However, this research found that ROA does not have a significant effect on Stock Return because ROA is determined by operating activities carried out by the company. The variability of a company's operating activities will affect the company's operating profit because operating conditions will reflect the business risk faced by investors. This risk is unsystematic (a risk that investors can avoid by diversifying). Based on its source, risk is divided into two: internal and external sources. Business risk that comes from internal concerns the efficiency of the company's operations under the control of the company, while business risks sourced from external or outside the company's control can be caused by interest costs and increases in tax rates, political and economic policies in which they will affect the company's profits. Most investors pay more attention to external risks in determining stock investment choices. This is what causes ROA not to have a significant effect on stock prices.

Determining the Effect of Earnings per Share (EPS) on Stock Return. The results of partial test (t-test) between the EPS variable and Stock Return variable obtain t calculate value of 2.076, the regression coefficient of 0.175 , and the probability value of 0.058 which is greater than 0.05. It means that EPS does not have significant effect on SOE Banks' Stock Returns. Therefore, the hypothesis stating that the EPS ratio has significant effect on Stock Return is rejected.

The analysis results showed that the EPS ratio does not have significant effect on Stock Return. It is indicated by a probability value of 0.058 which is greater than 0.05 . Therefore, changes in EPS do not cause significant changes in Stock Return obtained by investors. This research findings support Arista and Astohar (2012) who found that Earnings per Share (EPS) does not have effect on Stock Return but do not support Dwiastuti and Nugroho (2011) who found that Earnings per Share (EPS) has effect on Stock Return.

The research findings showed that EPS has no significant effect on Stock Return. In other words, even though the amount of money (rupiah) generated from each sheet of common stock in circulation is increasing, the stock returns that investors will receive will not necessarily increase. It is because there are still many other factors that affect Stock Return. It is common to know that Stock Return can be influenced by fundamental, market and macro factors. Since macro factors affect locally on an investment object, the fundamental and market factors need to be studied further. Fundamental factors are factors that are related to the issuer's company performance, while market factors are related to the performance of their shares. In addition, if the company's ability to generate profits increases, the stock price will increase. Increasing the company's stock price will make Stock Return higher. In this case, an increase in stock prices also encourages an increase in Stock Returns so that it can be concluded that although Earnings per Share experience an increase does not mean that it will increase Stock Return.

Determining the Effect of Inflation Rate on Stock Return. The results of partial test (ttest) between the Inflation Rate variable and Stock Return variable obtain t calculate value of 0.083 , the regression coefficient of 0.025 , and the probability value of 0.935 which is greater than 0.05. It means that Inflation Rate does not have significant effect on SOE Banks' Stock Returns. Therefore, the hypothesis stating that the Inflation Rate ratio has significant effect on Stock Return is rejected. 
The analysis results showed that the Inflation ratio does not have significant effect on Stock Return. It is indicated by a probability value of 0.935 which is greater than 0.05 . Therefore, changes in Inflation Rate do not cause significant changes in Stock Return obtained by investors. This research findings support Labibah (2016) who found that Inflation Rate does not have effect on Stock Return but do not support Nasir and Mirza (2013) who found that Inflation Rate has effect on Stock Return.

The findings showed that the inflation rate does not have effect on stock return. Inflation that occurs during the research period is below the level of $10 \%$ which is classified as low and stable. From the investor's point of view, the inflation rate below $10 \%$ is considered fair and stable and is not a determinant or explanatory factor in changes in Stock Return. Thus, investors pay more attention to how companies generate high profits in order to generate high returns for investors. Investors also believe that the company has a specific strategy in dealing with inflation in Indonesia. So, the inflation size does not affect the profits that will be obtained by the company. A specific strategy, that can be applied by the company so that the company's business activities continue to run, is to reduce unnecessary operational and marketing costs. Therefore, although company inflation occurs every year, banks are still able to earn profits and investors still get a return on investment in the company. Based on the above reasons, in making investment decisions, investors are not affected by changes in inflation that occur every year as long as the inflation rate is still considered reasonable and stable.

Determining the Effect of the Interest Rate on Stock Return. The results of partial test (t-test) between the Interest Rate variable and Stock Return variable obtain t calculate value of 2.985 , the regression coefficient of 2.021 , and the probability value of 0.011 which is smaller than 0.05. It means that Interest Rate has significant effect on SOE Banks' Stock Returns. Therefore, the hypothesis stating that the Interest Rate ratio has significant effect on Stock Return is accepted.

The analysis results showed that the Interest Rate ratio has significant effect on Stock Return. It is indicated by a probability value of 0.011 which is smaller than 0.05 . Therefore, changes in Interest Rate cause significant changes in Stock Return obtained by investors. This research findings support Aziz (2012) who found that Earnings per Share (EPS) has effect on Stock Return but do not support Dwialesi and Darmayanti (2011) who found that Interest Rate does not have effect on Stock Return.

The research findings indicated that changes in interest rate will affect stock prices in reverse; ceteris paribus. In other words, if interest rate increases, stock prices will decrease and vice versa (Tandelilin, 2001). This falling stock price will cause stock returns to decline. It is because in the face of rising interest rates, shareholders will hold their shares until the interest rate returns to a level that is considered normal. Conversely, if the long-term interest rate increases, the shareholders tend to sell their shares because the selling price is high. The increase in interest rates will be very influential for capital market players. Fluctuating interest rate movements, that tend to increase, will affect the movement of the real sector as reflected by the movement of stock returns. Due to the rising interest rates, capital owners would prefer to invest their money in the bank rather than investing in shares.

Determining the Effect of Return on Assets (ROA), Earnings per Share (EPS), Inflation Rate and Interest Rate simultaneously on Stock Return. The results of simultaneous test (F test) between the variables of Return on Assets (ROA), Earnings per Share (EPS), Inflation Rate, and Interest Rate on Stock Returns simultaneously obtain the Sig. value of 0.03 or < 0.05. It means that Return on Assets (ROA), Earnings Share (EPS), Inflation Rate and Interest Rate have a significant simultaneous effect on the Stock Return of SOE Banks. Therefore, the hypothesis stating that the ratios of Return on Assets (ROA), Earnings per Share (EPS), Inflation Rate and Interest Rate simultaneously have significant effect on Stock Return is accepted.

The research findings show that Return on Assets (ROA), Earnings Per Share (EPS), Inflation Rate and Interest Rate simultaneously have a good effect on Stock Return. It is in accordance with the Ang's theory (1997) which mentioned that there are two factors that affect the return of an investment: first, the company's internal factors such as the quality and 
reputation of its management, capital structure, corporate debt structure, and so forth (in this case, ROA and EPS); second, the external factors, for instance, the effect of monetary and fiscal policies, the development of the industrial sector, economic factors such as the occurrence of inflation, etc. which in this case, inflation rate and interest rate are used. We can see the number of possible factors to be an $X$ variable in affecting $Y$ variable, especially in terms of external factors of the company. In terms of external factor of the company, there are political factors that also affect the return of an investment. In addition, according to Tandelilin (2001), there are several sources of risk that can affect the size of the risk of an investment (stock return): interest rate risk, market risk, inflation risk, business risk, financial risk, liquidity risk, currency exchange risk, and country risk.

\section{CONCLUSION}

Based on data analysis and discussion of research results, the following conclusions can be drawn:

The research findings showed that the variables of Return on Assets (ROA), Earnings per Share (EPS), Inflation Rate and Interest Rate simultaneously have significant effect on Stock Return. It means that any changes that occur to the independent variables, Return on Assets (ROA), Earnings per Share (EPS), Inflation Rate and Interest Rate, simultaneously or jointly have an effect on Stock Return in SOE Banks in Indonesia.

Partially the variables of Return on Assets (ROA), Earnings per Share (EPS), Inflation Rate and Interest Rate which has an effect on Stock Return and the most dominant variable affecting Stock Return based on the research findings are as follows:

- Return on Assets (ROA) Variable does not have a significant effect on Stock Return in SOE Banks in Indonesia;

- Earnings per Share (EPS) Variable does not have a significant effect on Stock Return in SOE Banks in Indonesia;

- Inflation Rate Variable does not have a significant effect on Stock Return in SOE Banks in Indonesia;

- Interest Rate Variable has a significant effect on Stock Return in SOE Banks in Indonesia.

\section{REFERENCES}

1. Ang, J. S., Cole, R. A., \& Lin, J. W. (2000). Agency costs and ownership structure. the Journal of Finance, 55(1), 81-106.

2. Anisa, N. (2015). Analisis Faktor-Faktor yang Mempengaruhi Return Saham (Studi Kasus Pada Perusahaan Sub Sektor Automotive And Components yang Terdaftar di Bursa Efek Indonesia Periode 2010-2014). Perbanas Review, 1(01).

3. Arista, D., \& Astohar, A. (2012). Analisis Faktor-Faktor Yang Mempengaruhi Return Saham. Jurnal IImu Manajemen dan Akuntansi Terapan, 3(1).

4. Asna, A., \& Graha, A. N. (2006). Analisis Pengaruh Rasio Keuangan Terhadap Return Saham Perbankan Yang Terdaftar Di Bursa Efek Jakarta. Jurnal Ekonomi Modernisasi, 2(3), 192-212.

5. Darmadji, T., \& Fakhruddin, H. M. (2001). Pasar modal di Indonesia: Pendekatan tanya jawab. Salemba empat.

6. Dwialesi, J. B., \& Darmayanti, N. P. (2016). Pengaruh Faktor-Faktor Fundamental Terhadap Return Saham Indeks Kompas 100. E-Jurnal Manajemen Unud, 5(4), 25442572.

7. Dwiastuti, M. M. P., \& Nugroho, D. A. (2011). Pengaruh Earning Per Share, Price Earning Ratio, Quick Ratio Terhadap Return Saham Pada Perusahaan Manufaktur di Bei Periode 2004-2008. Jurnal Ekonomi dan Kewirausahaan, 7(14).

8. Hardiningsih, Pancawati, Suryanto. L, Chariri, Anis, (2002), Pengaruh Faktor Fundamental dan Risiko Ekonomi Terhadap Return Saham Pada Perusahaan di Bursa 
Efek Jakarta (Studi Kasus Basic Industry \& Chemical), Jurnal Strategi Bisnis, Vol. 8 Th. VI pp. 83-96

9. Iannotta, G. (2014). Investment banking. Springer.

10. Labibah, S. (2016). Pengaruh Variabel Inflasi, Suku Bunga Dan Nilai Tukar Terhadap Return Saham Dengan Risiko Sistematis (Beta) Sebagai Variabel Intervening (Studi Pada Perusahaan Sub Sektor Makanan Dan Minuman Yang Terdaftar Di Bei Periode 2011-2015). Thesis. Universitas Islam Negeri Maulana Malik Ibrahim Malang.

11. Nasir, A., \& Mirza, A (2013). Pengaruh Nilai Kurs, Inflasi, Suku Bunga Deposito Dan Volume Perdagangan Saham Terhadap Return Saham Pada Perusahaan Perbankan Yang Terdaftar Di Bursa Efek Indonesia. Jurnal Universitas Riau.

12. Ratna Prihantini, Se. 2009. Analisis Pengaruh Inflasi, Nilai Tukar, ROA, DER Dan CR Terhadap Return Saham (Studi Kasus Saham Industri Real Estate And Property Yang Terdaftar Di Bursa Efek Indonesia Periode 2003 - 2006). Tesis Magister Manajemen Universitas Diponegoro. Semarang.

13. Tandelilin, Eduardus. 2001. Analisis Investasi Dan Manajemen Portofolio. Yogyakarta: BPFE. 